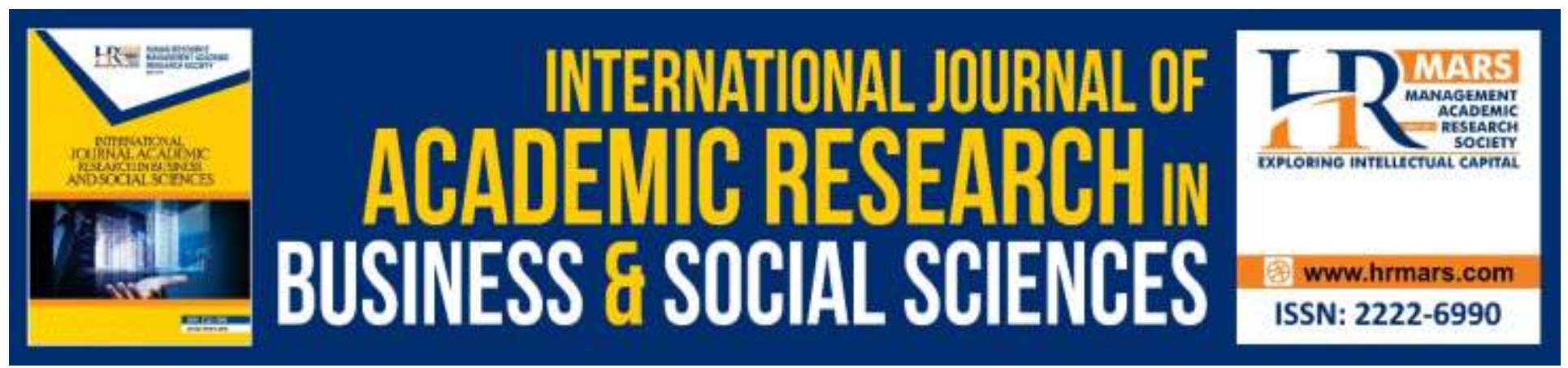

\title{
Ideology, Communication, and Response to Terrorism: A Sharia-based Perspective
}

\section{Adnan Tawfiq Mohd, Anas Mohd Yunus, Isyaku Hassan}

To Link this Article: http://dx.doi.org/10.6007/IJARBSS/v10-i3/7029

DOI:10.6007/IJARBSS/v10-i3/7029

Received: 02 February 2020, Revised: 22 February 2020, Accepted: 12 March 2020

Published Online: 27 March 2020

In-Text Citation: (Mohd et al., 2020)

To Cite this Article: Mohd, A. T., Yunus, A. M., \& Hassan, I. (2020). Ideology, Communication, and Response to Terrorism: A Sharia-based Perspective. International Journal of Academic Research in Business and Social Sciences, 10(3), 124-130.

Copyright: (C) 2020 The Author(s)

Published by Human Resource Management Academic Research Society (www.hrmars.com)

This article is published under the Creative Commons Attribution (CC BY 4.0) license. Anyone may reproduce, distribute, translate and create derivative works of this article (for both commercial and non-commercial purposes), subject to full attribution to the original publication and authors. The full terms of this license may be seen at: http://creativecommons.org/licences/by/4.0/legalcode

Vol. 10, No. 3, 2020, Pg. 124 - 130

Full Terms \& Conditions of access and use can be found at http://hrmars.com/index.php/pages/detail/publication-ethics 


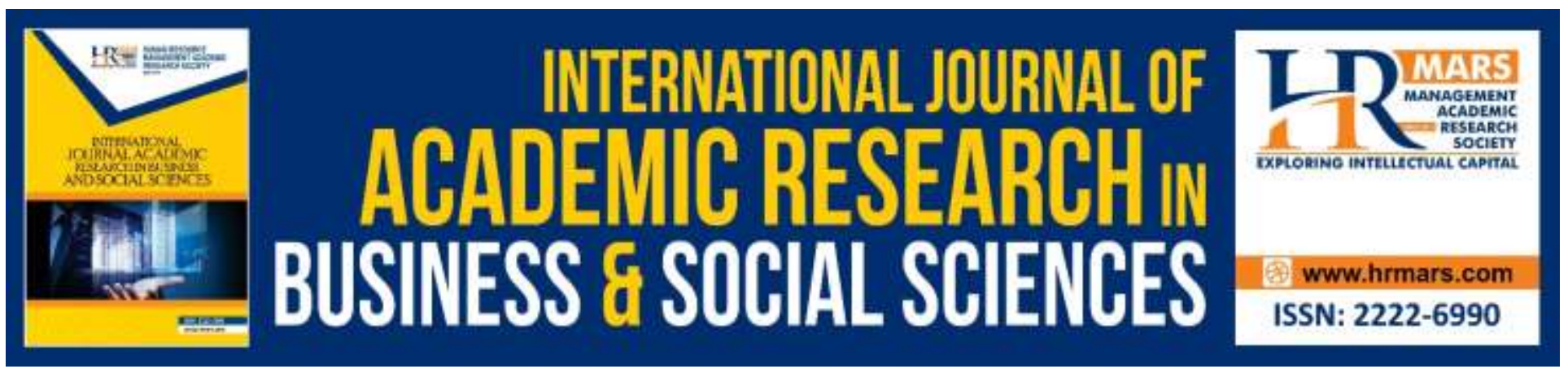

\title{
Ideology, Communication, and Response to Terrorism: A Sharia-based Perspective
}

\author{
Adnan Tawfiq Mohd ${ }^{1}$, Anas Mohd Yunus ${ }^{1}$, Isyaku Hassan² \\ ${ }^{1}$ Faculty of Islamic Contemporary Studies, Universiti Sultan Zainal Abidin, Gong Badak, 21300 Kuala \\ Nerus, Terengganu, Malaysia, ${ }^{2}$ Faculty of Languages and Communication, Universiti Sultan Zainal \\ Abidin, Gong Badak, 21300 Kuala Nerus, Terengganu, Malaysia \\ Email: mesterjordan78@gmail.com
}

\begin{abstract}
Counter-ideological response is necessary in neutralizing and defeating terrorism. This is because ideology plays an important role in the formation of terrorist propaganda to attract followers. The situation requires various strategies, including delivery of genuine religious messages, to address the terrorists' ideological motives which could be ethno-nationalistic or politico-religious in nature. Though terrorists generally share common goals and certain common approaches, many terrorist organizations claim to be Muslims and carry out attacks in the name of Islam. Hence, this paper aims to explain how effective ideological response could help in defeating global terrorism. The paper uses inductive analytical method in which corroborating evidence was obtained from previous literature, Quran and Sunnah (Prophetic Traditions). This paper argues that ideological response to terrorist organizations, such as the Islamic States of Syria and Iraq (ISIS) and Al-Qaida, could be successful through a genuine understanding of Sharia, especially if communicated effectively. The fight against terrorism through military measures alone is likely to augment tension and hatred and serve to intensify the terrorists' global threat. The discussion in this conceptual paper could advance our understanding of the approaches to combating the misguided ideology of the present-day terror groups.
\end{abstract}

Keywords: Counter-Ideology, Military Measures, Sharia, Terror Group, Terrorism.

\section{Introduction}

As a widespread phenomenon, terrorism has increased in recent years (Piazza, 2009; Schouten, 2010). Since the $9 / 11$ attacks, the United States has formed various collaborations to combat terrorism at both local and international levels, and huge amount of money has been spent to finance the "war against terrorism". Nevertheless, defeating the terrorists' ideology through intelligence operations, which requires different skills and actions, has always been considered a secondary priority (Ryan, 2018). According to Rana (2008), counter-ideological response is necessary in 
INTERNATIONAL JOURNAL OF ACADEMIC RESEARCH IN BUSINESS AND SOCIAL SCIENCES Vol. 10, No. 3, March, 2020, E-ISSN: 2222-6990 @ 2020 HRMARS

neutralizing and defeating terrorism. This is because ideology plays an important role in the formation of terrorist propaganda to attract followers. Researchers argue that military measures or policy response are not adequate enough to fight against terrorism (Hassan, 2006; Rana, 2008). The situation requires various strategies to address the terrorists' ideological motives which could be "ethno-nationalistic or politico-religious in nature" (Hassan, 2006, p. 531).

Though terrorists generally share common goals and certain common approaches, many terrorist organizations claim to be Muslims and carry out attacks in the name of Islam. It should be noted that the terrorists' ideology contradicts the teaching of Islam, because none of the divine religions advocates violence (Hassan, Azmi, \& Abubakar, 2017). Therefore, resistance to the ideological motives of the terrorist organizations, such as ISIS and Al-Qaida should be based on divine religious scriptures and a genuine understanding of Sharia. In this regard, non-Islamic ideology appears to be irrelevant. The fight against terrorism through military measures alone is likely to augment tension and hatred and serve to intensify the terrorists' global threat. Different religious, cultural and contextual realities must be taken into consideration in the fight against terrorism (Hassan \& Pereire, 2006).

Despite the efforts of military and security agents to combat terrorism, the acts of terror increases across the globe (Hamele, Poss \& Sweney, 2014). This is because military machines cannot destroy ideology. Though it has been generally recognized that ideological response to the terrorist groups' propaganda is an important approach in the fight against terrorism, choosing the most appropriate strategy is still debatable (Hassan, 2006). Since the terrorist organizations claim that their ideology is based on Islamic law, an important approach to defeating their ideology must be based what they claim - Islamic thought. Previous studies confirmed that ideological response to terrorism could be an effective means of countering terrorism (Hassan, 2006; Hassan \& Pereire, 2006; Rana, 2008; Ramakrishna, 2016), but none of these studies focused mainly on how global terrorism could be combated through ideological response from Sharia perspective. Therefore, this paper discusses on how the misguided ideology of terrorist groups could be defeated based on ideological response from Sharia perspective, especially if the true message of Islam is effectively communicated. The concepts discussed in this paper could advance our understanding of the approaches to combating the misguided ideology of terrorist organizations.

\section{Misguided Ideological Motives of Terror Groups}

Terrorists organizations, such as the Islamic States of Iraq and Syria (ISIS), Al-Qaida, Al-Shabaab and Boko Haram carry out attacks in the name of Islam. They misinterpret Islamic scriptures - Quran and Hadith - for their ideological motives. As a result of their misinterpretation of the religious scriptures, these terror groups adopt the killing of innocent people as part of the key strategies in carrying out their violent acts. It should be noted that a sound ideology would never result in such kind of cruelty and misguidance. In Islam, killing of innocent human beings, both Muslims and non-Muslims, is completely forbidden. The Almighty Allah stated in the Quran:

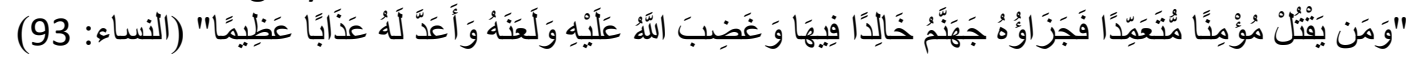

"But whoever kills a believer intentionally - hid recompense is Hell, wherein he will abide eternally, and Allah has become angry with him and has cursed him and has prepared for him a great punishment" (Q4:93). 
INTERNATIONAL JOURNAL OF ACADEMIC RESEARCH IN BUSINESS AND SOCIAL SCIENCES

Vol. 10, No. 3, March, 2020, E-ISSN: 2222-6990 @ 2020 HRMARS

In the address delivered by the Prophet (SAW) on the occasion Farewell Hajj, he said: "Your lives and properties are forbidden to one another till you meet your Lord on the Day of Resurrection" (Sahih al-Bukhari 7447, Book 97, Hadith 73). In addition, terrorists who claim to be Muslims try to impose Islamic thought on everyone by means of coercion, which is contrary to Sharia. The Almighty Allah says:

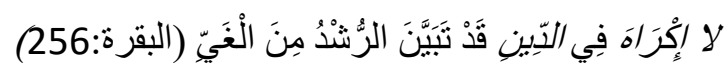

"There shall be no compulsion in [acceptance of] the religion. The right course has become clear from the wrong" (Q2:256).

The terrorist leaders typically use nicknames for security reasons. They cover their real names by bearing the nicknames belonging to well-known figures in Islamic history, mostly the Prophet's companions. For instance, the real name of Abu Bakr al-Baghdadi (The leader of ISIS) is Ibrahim Awad Ibrahim Badri (Rubin, 2014). Likewise, the real name of Abu Musab al-Zarqawi is Ahmed Fadil Nazzal Khalayleh. He was given the nickname "Al-Zarqawi" instead of his ethnicity "Bani Hassan", the largest tribe in Jordan. In reality, the purpose of using such nicknames is contrary to the good personality of the Prophet's companions, and the actions of terrorist groups are incompatible with the biography of the companions.

Nu'aym ibn Hammad narrated that the 4th Caliph, Ali ibn Abi Talib said: When you see the black flags, remain where you are and do not move your hands or your feet. Thereafter there shall appear a feeble insignificant folk. Their hearts will be like fragments of iron. They will have the state. They will fulfil neither covenant nor agreement. They will call to the truth, but they will not be people of the truth. Their names will be parental attributions, and their aliases will be derived from towns. Their hair will be free-flowing like that of women. This situation will remain until they differ among themselves. Thereafter, God will bring forth the Truth through whomever He wills (The book of Alfitan, Hadith no. 573).

The above Hadith, which was related by Al-Bukhari's teacher ( $\mathrm{Nu}^{\prime}$ aym bin Hamad), refers to the present-day ideology of terror groups. The Hadith refers to how and from where the terrorist leaders take their names "Their names will be parental attributions, and their aliases will be derived from towns". The use of nicknames by the terror groups claiming Islam indicates the ignorance of these groups because their actions contradict the Quran and the Sunnah. This situation also demonstrates how their ideology contradicts the teaching of Sharia. The names of terror group leaders must be exposed. This is because the leaders, who use Islamic religion as a cover for their misguided propaganda. At times, the names of terrorist organizations are coined either by the media or the international intelligence agencies fighting these organizations.

In sum, terrorist organizations misinterpret Islamic scriptures for their ideological motives which results in the killing of innocent people, cruelty and misguidance of their followers. There is not a single verse from the Quran or Hadith that supports the killing of innocent human beings. In fact, none of the divine religions advocates violence. The Prophet (peace be upon him) explained clearly about protection of lives irrespective of religious affiliations or race (Sahih al-Bukhari 7447, Book 97, Hadith 73). The terrorists try to impose Islamic thought on everyone by means of coercion, which is contrary to the teaching of Sharia. In addition, they cover their real names by bearing the nicknames belonging to well-known figures in Islamic history, mostly the Prophet's companions. This kind of people have been described in a Prophetic Hadith (The book of Al-fitan, Hadith no. 573). 
INTERNATIONAL JOURNAL OF ACADEMIC RESEARCH IN BUSINESS AND SOCIAL SCIENCES Vol. 10, No. 3, March, 2020, E-ISSN: 2222-6990 @ 2020 HRMARS

\section{The Role of Sharia in Combating Terrorism}

Sharia, which is considered as one of the major legal systems, plays an important role in regulating the affairs of Muslim societies (Ahmad, 2001). According to terror groups generally recognize Sharia as the supreme law and the only source for all kinds of legislation. It consists of rules and regulations derived from the Quran and Sunnah with comprehensive guide and solution to the entire problems facing mankind. Therefore, if the terrorists are genuine Muslims, they have no choice other than to abide by Sharia, which prohibits the killing of innocent human beings. Sharia is seen as an alternative to secular ideologies in the fight against terrorism. Terror acts and suicide bombing are completely forbidden in Islam and are not the form of Jihad or martyrdom of any kind (Hassan, 2007).

Sharia is an important approach in neutralizing and combating terrorism, which has been successfully applied in countries like Saudi Arabia. For example, in its effort to combat terrorism, the Saudi government adopted an "advisory strategy defined by two approaches: prevention, draining the sources of extremism through correcting the flawed understanding of Sharia, and treatment, using frank dialogue, bridge-building and confrontation, to encourage those who sympathize with terrorists to recant" (Ansary, 2008, p. 118). Various means of communication such as the internet were utilized to discuss and find solutions the misguided ideology of the extremists. The Saudi government realized that combating terrorism through military measures rather than on ideology was inappropriate.

As discussed in the previous section, terror groups such as ISIS, Al-Qaida, Al-Shabaab, and Boko Haram misinterpret divine scriptures to attract, recruit and mobilize their followers. Exposing the misguided ideology of terror groups, particularly those who carry out attacks in the name of Islam, could be a potential means of combating terrorism (Ansary, 2008). This could be done by showing their ignorance of Quranic texts and their implications. In this regard, the role of Sharia experts could be demonstrated by addressing the root causes of misinterpretations of the Quranic verses through various strategies, such as public lectures, debates and online programs. Such efforts could be communicated by means of educating not only those who have relationship with the terror groups but also the entire people (Muslims and non-Muslims). The principle of Maslaha (public interest) and Maqasid Shariah (objective of the Sharia) support the peaceful coexistence of Muslims and nonMuslims in the West and aim to safeguard basic rights and liberty based on Islamic law.

The military solution in relation to terrorism only increases the terrorists' ignorance about religion because it does not address the main causes. The physical confrontation strengthens the organizations and increases their spread (Hassan \& Pereire, 2006). The terrorist organizations could easily be defeated by means of intellectual confrontation based on their claim because they depend on ideology to attract followers. The ideological response to terrorism based on Sharia must consider the seriousness of this phenomenon. In addition, arguments might be built from the main sources of Sharia (Quran \& Sunnah) by revealing the weakness of the terrorists' ideological motives. Islamic scholars can also play an important role in educating the masses (bother Muslims and non-Muslims) about the values of religious beliefs and morals. Confronting this scourge by focusing on education will yield expose the danger of terrorism and prevent others having such erroneous ideology.

Protection of life paramount, and an important provision of Sharia that elevates and protect the dignity of human beings is protection of life (Hayatli, 2012). Sharia recognizes respect for human dignity. The provisions of Sharia declare the dignity of human beings and emphasizes that any attack on the life of human beings, irrespective of religious affiliation, is completely forbidden. Besides, it is the duty of Muslims to convey the message of Islam, including the provisions of Sharia on the 
INTERNATIONAL JOURNAL OF ACADEMIC RESEARCH IN BUSINESS AND SOCIAL SCIENCES Vol. 10, No. 3, March, 2020, E-ISSN: 2222-6990 @ 2020 HRMARS

protection of life, with wisdom through correspondences such as public lecture, teaching, and preaching by means of clear jurisprudence or legal texts, which call for the protection human beings from attacks. The Almighty Allah says:

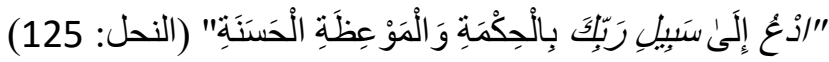

Invite to the way of your Lord with wisdom and good instruction, and argue with them in a way that is best (Q16: 125).

In addition to the aforementioned verse of the Noble Quran, the Prophet (peace be upon him) was reported to have said:

$$
\text { "بلغوا عني ولو آية وحدثو ا عن بني إسر ائيل ولا حرج، ومن كذب علي متعدًا فليتبو أ مقعده من النار" (رواه البخاري). }
$$

"Convey from me even an Ayah of the Qur'an; relate traditions from Banu Israel, and there is no restriction on that; but he who deliberately forges a lie against me let him have his abode in the Hell" (Al- Bukhari, Book 13, Hadith no. 5).

The importance of Islamic law is recognized globally. Ahmad (2001) argues that "for the international community in general, and the United States in particular, to achieve and maintain long-term success in their mission with the Muslim world, it is imperative to engage Islamic law principles rather than the current embrace of unrepresentative Muslim governments" (p. 157). To address terrorism, appropriate ideological response is necessary, especially from Sharia perspective. To demonstrate the importance of ideological response in the fight against terrorism, Ramakrishna (2016) developed a model of counter-ideological response for countering terrorism, which consists of conceptual communication components of sender, message, mechanism, recipient and context. Sharia messages, if genuinely communicated, could be an important means of ideological response to terrorism (Ansary, 2008).

\section{Conclusion}

This paper discussed the relevance of ideological response to terrorism from Sharia perspective. It is evident that the present-day terrorist organizations were described in the Prophetic Hadith. The discussion in this paper shows that an important approach to combating terrorism is by exposing the mistakes in their ideology through various means, including the modern media technology. Hence, the ideological response must be based on Sharia, as many terror groups claim that their ideology is based on religious texts. However, the messages of Quran and Prophetic Hadith are clear about the severity of punishment for killing of innocent human beings. The Prophet (peace be upon him) explained clearly about protection of lives irrespective of religious affiliations or race. Terrorist who claim to be Muslims misinterpret religious scriptures, especially Quranic texts. In this regard, the root causes of these misinterpretations must be addressed by disseminating the genuine teaching of Sharia through various strategies, such as online media, public lectures, debates and online programs. The evidence provided in this paper is an initial exploration of how Sharia-based ideological response could help curtail global terrorism. Therefore, future studies may consider a more rigorous analysis using mixed methods approach. 
INTERNATIONAL JOURNAL OF ACADEMIC RESEARCH IN BUSINESS AND SOCIAL SCIENCES

Vol. 10, No. 3, March, 2020, E-ISSN: 2222-6990 @ 2020 HRMARS

\section{References}

Bouzid, A. (2017). The Reason for Naming Abu Lahab in the Holy Quran. Cairo. Noon Magazine.

Abdullah, A., Marouzi, N. bin. H. bin. M. B. H. K. (2010). Alfitan. Cairo. Tawheed.

Ahmad, A. (2001). The role of Islamic law in the contemporary world order. J. Islamic L. \& Culture, 6 (1), 157-169.

Ansary, A. F. (2008). Combating extremism: A brief overview of Saudi Arabia's approach. Middle East Policy, 15(2), 111.doi: 10.1111/j.1475-4967.2008.00353.x

Hamele, M., Poss, W. B., \& Sweney, J. (2014). Disaster preparedness, pediatric considerations in primary blast injury, chemical, and biological terrorism. World journal of critical care medicine, 3(1), 15-23.doi: 10.5492/wjccm.v3.i1.15

Hassan, I., Azmi, M. N., \& Abubakar, U. I. (2017). Framing Islam in news reporting: A Comparative content analysis. Asian Social Science, 13(10), 112-119. doi:10.5539/ass.v13n10p112

Hassan, M. H. B. (2006). Key considerations in counterideological work against terrorist ideology. Studies in Conflict \& Terrorism, 29(6), 531-558.doi: 10.1080/10576100600791058

Hassan, M. H., \& Pereire, K. G. (2006). An ideological response to combating terrorism-The Singapore perspective. Small Wars and Insurgencies, 17(4), 458-477.doi: 10.1080/09592310601060815

Hasan, N. (2007). Islamic militancy, sharia, and democratic consolidation in post-Suharto Indonesia. Retrieved from: https://dr.ntu.edu.sg/handle/10356/79795

Hayatli, M. (2012). Islam, international law and the protection of refugees and IDPs. Forced Migration Review, 2. Retrieved from: https://search.proquest.com/

Piazza, J. A. (2009). Is Islamist terrorism more dangerous?: An empirical study of group ideology, organization, and goal structure. Terrorism and Political Violence, 21(1), 62-88.doi: 10.3109/10673229.2010.533005

Ramakrishna, K. (2016). Towards a comprehensive approach to combating violent extremist ideology in the digital space: The counter-ideological response (CIR) model. In Combating Violent Extremism and Radicalization in the Digital Era (pp. 260-282). IGI Global.doi: 10.4018/978-15225-0156-5.ch013

Rana, M. A. (2008). Counter-ideology: Unanswered questions and the case of Pakistan. Perspectives on Terrorism, 2(3), 3-5. https://www.jstor.org/stable/26298334

Rubin, A. J. (2014). Militant Leader in Rare Appearance in Iraq. The New York Times. Retrieved 22 July 2019. https://www.nytimes.com/2014/07/06/world/asia/iraq-abu-bakr-al-baghdadisermon-video.html

Ryan, M. W. (2018). Defeating ISIS and Al-Qaeda on the Ideological Battlefield: The Case for the Corporation Against Ideological Violence. Retrieved from: https://digitalcommons.usnwc.edu/ciwag-case-studies/16/

Schouten, R. (2010). Terrorism and the behavioral sciences. Harvard review of psychiatry, 18(6), 369378.doi: 10.1080/09546550802544698. 